\title{
Computational modelling of the heat transfer through two-layer woven structure ensembles
}

DOI: 10.35530/IT.071.03.1653

\section{ABSTRACT - REZUMAT}

\section{Computational modelling of the heat transfer through two-layer woven structure ensembles}

The purpose of the present study was to investigate the heat transfer through a system of two consecutive textile layers with woven macrostructures by numerical simulation, using FLUENT CFD software package. A novel approach for modelling of the textile structure was applied, based on jet systems. The heat transfer through the systems of layers was studied for indoor conditions, simulating skin and indoor air temperature, as well as the effect of the convective cross flow around the human body. The results of the study showed that the heat transfer through a system of two layers is strongly influenced by the porosity and thickness of the fabrics, as well as their arrangement in the systems as an insulating barrier between the body and the environment.

Keywords: systems of layers, woven textiles, jet system, CFD, FLUENT

Modelarea computațională a transferului de căldură prin ansambluri din două straturi de structuri țesute

Scopul prezentului studiu a fost investigarea transferului de căldură printr-un sistem format din două straturi textile consecutive cu macrostructuri țesute prin simulare numerică, folosind pachetul software FLUENT CFD. A fost aplicată o nouă abordare pentru modelarea structurii textile, bazată pe sisteme cu jet. Transferul de căldură prin sistemele de straturi a fost studiat pentru condiții interioare, simulând temperatura pielii și a aerului din interior, precum și influența fluxului transversal de căldură prin convecție în jurul corpului uman. Rezultatele studiului au arătat că transferul de căldură printr-un sistem format din două straturi este puternic influențat de porozitatea și grosimea țesăturilor, precum și de dispunerea acestora în sistem ca o barieră izolatoare între corp și mediu.

Cuvinte-cheie: sisteme de straturi, materiale textile țesute, sistem jet, CFD, FLUENT

\section{INTRODUCTION}

The thermophysiological comfort of a clothed body is a very complex problem, since clothing is an integral part of the heat exchange between the human and the environment. Henry [1] developed one of the first theories on the heat transfer through a textile barrier, taking into account the cumulative effects of the layers. A model with both convective and diffusive mechanisms of heat transfer through clothing was presented by Ogniewicz et al. [2]. Farnworth [3] proposed a relatively simple dynamic model, which included heat transfer by radiation and thermal conductivity, as well as diffusion transfer of moisture, accounting the effect of the fabric surface. Detailed dynamic modelling was performed later by Fan et al. [4]. Mathematical model for the transfer of heat and moisture through different samples of textiles was presented by Wissler et al. [5]. Dynamic model of the characteristics of heat and vapour transfer was introduced by Li et al. [6], following the double-layer model of the human thermoregulation [7]. A very detailed model with 40 segments of the human skin and a textile layer on it was developed by De Dear et al. [8]. Thereafter models of human thermoregulation were presented by $\mathrm{Xu}$ and Fiala et al. [9-10], where both the heat and vapour transfer through textile layers and the effect of absorption by the textile layers were included.

The consecutive layers of fabrics affect the thermal insulation of the clothing and the thermophysiological comfort, including the comfort of bedridden people [11], as the system of layers has different characteristics from the compound single layers. The main reasons for that are the change in the porosity of the single layers and the appearance of an air layer. The porosity of the system of layers cannot be calculated, as it is done in the case of single layers; the thickness of the air layer between two textile layers is also unknown. Therefore, it is difficult to estimate quantitatively how the porosity of the system has changed, on the first place, and how the transfer of heat in through-thickness direction of the system is affected, on the second. Though the problem of heat transfer through a system of textile layers has been investigated experimentally, our literature survey has shown that the simulation of heat transfer through two consecutive layers of textiles has not been studied numerically, using the possibilities of the Computational Fluid Dynamics (CFD). Therefore, the aim of the present study was to use a method for simulation of the 
structure of woven fabrics, which has been verified and applied for simulation of heat transfer through single layer woven fabrics [12]. The simulation allowed making an analysis of the effect of the fabrics' characteristics and the arrangement of the layers in the system on the heat transfer process in through-thickness direction of the textiles.

\section{MATERIALS AND METHODS}

\section{Mathematical model}

FLUENT 6.3 general purpose CFD software package was used to perform the numerical simulations. The mathematical model was based on the Reynolds averaged Navier-Stokes (RANS) partial differential equations and the continuity equation. The energy equation, implemented in FLUENT, was included to simulate the heat transfer:

$$
\begin{gathered}
\frac{\partial}{\partial t}(\rho E)+\nabla[\vec{v}(\rho E+p)]= \\
=\nabla\left[k_{\text {eff }} \nabla T-\sum_{j} h_{j} \vec{J}_{j}+\left(\overline{\bar{\tau}}_{\text {eff }} \vec{v}\right)\right]+S_{h}
\end{gathered}
$$

where $\rho$ is the density of the fluid $\left(\mathrm{kg} / \mathrm{m}^{3}\right), E-$ the energy, $\vec{v}$ - the velocity vector, $p-$ the pressure $(\mathrm{Pa})$, $T$ - the temperature $(\mathrm{K}), k_{\text {eff }}$ - the effective conductivity, $h_{j}$ - the sensible enthalpy, $\vec{J}_{j}$ - the diffusion flux of species $j, \overline{\bar{\tau}}_{\text {eff }}$ - the effective viscous stress tensor, $S_{h}$ - a term for the heat transfer of chemical reactions and any other heat sources defined.

The effective conductivity $k_{\text {eff }}$ was defined as:

$$
k_{\text {eff }}=k+k_{t}
$$

where $k$ is the thermal conductivity of the material and $k_{t}$ - the turbulent thermal conductivity.

To solve the closure problem, $k-\varepsilon$ turbulence model was applied, together with the SIMPLE algorithm and a second-order upwind difference scheme.

\section{Fabrics data}

Five samples of $100 \%$ cotton woven fabrics with different characteristics were selected to create systems of two layers. Table 1 summarizes the fabrics data: mass per unit area, warp and weft densities, linear density of the yarns used, thickness, porosity, and mean pore area. The porosity $V_{s}, \%$ was calculated, following the expression:

$$
V_{s}=100-\left(E_{w a}+E_{w f}-0.01 E_{w a} E_{w f}\right)
$$

where $E_{w a}(\%)$ and $E_{w f}(\%)$ are both warp and weft cover factors, calculated via the samples' warp $P_{\text {wa }}$ (ends/dm) and weft density $P_{w f}$ (picks/dm), the linear density of the warp $T t_{w a}$ (tex) and weft threads $T t_{w f}$ (tex), respectively:

$$
E_{w a}=k_{f} P_{w a} \sqrt{\frac{T t_{w a}}{1000}} \text { and } E_{w f}=k_{f} P_{w f} \sqrt{\frac{T t_{w a}}{1000}}
$$

where $k_{f}$ is a coefficient that depends on the material. It is noteworthy that the five selected samples covered a range of fabric weight from $89 \mathrm{~g} / \mathrm{m}^{2}$ to 202 $\mathrm{g} / \mathrm{m}^{2}$, thickness from $0.39 \mathrm{~mm}$ to $0.71 \mathrm{~mm}$ and areal porosity of $51.6 \%$ to $8.9 \%$. The mean pore area was measured experimentally (100 measurements per sample) with a microscope Optika DM-15 with a builtin digital camera, following the procedure in [13].

\section{Simulated cases and boundary conditions}

The geometry of each woven sample was built on the basis of a transformation method, described and verified in [19]. Each pore of the woven macrostructure was considered as an opening of a jet; thus the plane of the sample was presented as an in-corridor ordered jet system that consisted of a set of $3 \times 3$ jets (figure 1). According to the jet-system theory [14], every central jet is representative for the whole system, as the surrounding eight jets play the role of boundary conditions for the central jet. The geometry of each sample was built with FLUENT's GAMBIT pre-processor. A pipe-like domain was used for the simulation: the first sample (with thickness of $x_{1}$ ) was built $3 \mathrm{~mm}$ after the domain inlet and $8 \mathrm{~mm}$ before the domain outlet. The second sample (with thickness of $\mathrm{x}_{2}$ ) was immersed at a distance of $1 \mathrm{~mm}$ after the first sample.

Due to the different size of the samples (thickness of the yarns and size of the pores) the cross section of

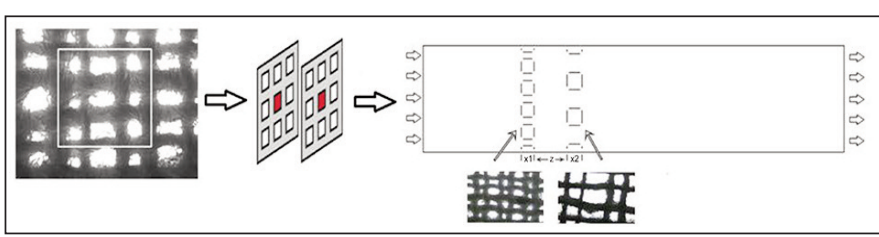

\begin{tabular}{|c|c|c|c|c|c|c|c|c|}
\hline $\begin{array}{c}\text { Sample } \\
\text { code }\end{array}$ & $\begin{array}{c}\text { Mass per } \\
\text { unit area } \\
\left(\mathrm{g} / \mathrm{m}^{2}\right)\end{array}$ & $\begin{array}{c}\text { Warp } \\
\text { density } \\
\text { (ends/dm) }\end{array}$ & $\begin{array}{c}\text { Weft } \\
\text { density } \\
\text { (picks/dm) }\end{array}$ & $\begin{array}{c}\text { Linear } \\
\text { density warp } \\
\text { (tex) }\end{array}$ & $\begin{array}{l}\text { Linear } \\
\text { density weft } \\
\text { (tex) }\end{array}$ & $\begin{array}{l}\text { Thickness } \\
(\mathrm{mm})\end{array}$ & $\begin{array}{c}\text { Porosity } \\
\text { (\%) }\end{array}$ & $\begin{array}{l}\text { Mean pore } \\
\text { area } S_{m} \\
\left(\mathrm{~mm}^{2}\right)^{2}\end{array}$ \\
\hline K & 89 & 176 & 124 & 28 & 28 & 0.45 & 51.6 & 0.255 \\
\hline $\mathrm{P}$ & 133 & 284 & 294 & 20 & 20 & 0.39 & 29.1 & 0.038 \\
\hline$Y$ & 157 & 234 & 254 & 30 & 30 & 0.47 & 23.3 & 0.031 \\
\hline$S$ & 184 & 383 & 338 & 30 & 30 & 0.68 & 13.5 & 0.023 \\
\hline $\mathrm{R}$ & 202 & 386 & 226 & 30 & 30 & 0.71 & 8.9 & 0.014 \\
\hline
\end{tabular}

Fig. 1. Approximation method for building a system of two woven layers, based on the jet system theory

BASIC CHARACTERISTICS OF THE SIMULATED WOVEN MACROSTRUCTURES 
Table 2

SIMULATED CASES WITH DATA FOR THE GRID

\begin{tabular}{|c|c|c|c|c|c|}
\hline Case & $\begin{array}{c}\text { First } \\
\text { layer }\end{array}$ & $\begin{array}{c}\text { Second } \\
\text { layer }\end{array}$ & $\begin{array}{c}\text { Number } \\
\text { of cells }\end{array}$ & $\begin{array}{c}\text { Number } \\
\text { of faces }\end{array}$ & $\begin{array}{c}\text { Number } \\
\text { of nodes }\end{array}$ \\
\hline 1 & $\mathrm{P}$ & $\mathrm{K}$ & 152729 & 422556 & 124032 \\
\hline 2 & $\mathrm{~K}$ & $\mathrm{P}$ & 158761 & 440652 & 130064 \\
\hline 3 & $\mathrm{P}$ & $\mathrm{Y}$ & 76561 & 221373 & 70473 \\
\hline 4 & $\mathrm{Y}$ & $\mathrm{P}$ & 71689 & 206757 & 65601 \\
\hline 5 & $\mathrm{P}$ & $\mathrm{S}$ & 425966 & 1071864 & 219064 \\
\hline 6 & $\mathrm{P}$ & $\mathrm{R}$ & 1318777 & 3012569 & 531513 \\
\hline
\end{tabular}

the computational domain was built, applying the following requirements: (i) the axis of the central pore of the two consecutive layers of fabrics to be one and the same; (ii) the model of each woven macrostructure to involve at least $9(3 \times 3)$ pores (a tightly woven macrostructure involves more pores than the loosely woven macrostructure).

Six cases were simulated (table 2). Two types of grids were applied: a structured hexagonal grid, for meshing both the woven macrostructures and the numerical domain before and after the samples, and a hybrid grid in the space between the two samples. The data for the grid's cells, nodes and faces are shown in table 2. Obviously, Cases 5 and 6 had the most complex girds.

Temperature of $36^{\circ} \mathrm{C}$ was set at the inlet wall of the domain (hot wall) and $22^{\circ} \mathrm{C}$ at the inlet wall (cold wall), to simulate the heat transfer between the human skin and the temperature of the air in an air-conditioned indoor environment through the system of textiles. Symmetric boundary conditions were set on the three of the side walls of the domain. On the fourth wall a transversal convective flow (velocity $0.5 \mathrm{~m} / \mathrm{s}$ ) was set immediately after the second textile layer to simulate the natural convective flow around a human body.

\section{RESULTS AND DISCUSSIONS}

The effect of the characteristics of the layers

Figure 2 summarizes the temperature fields for Cases 1, 3, 5 and 6. The thickness and the mass per unit area of the second layer is increasing (from figure 2, a to $d$ ), thus increasing these parameters of the system. At the same time the porosity of the second layer is decreasing (from figure 2, a to $d$ ). The numerical results for the temperature field clearly show the influence of the characteristics of the layers on the heat transfer through the system. Due to the high porosity of Sample K $(51.6 \%)$, the heat transfer through the two layers is intensive (figure 2,a). The textile barrier has little resistance to the main flow at the outlet of the first layer (Sample P) and the main flow deforms the convective cross flow, creating conditions for intensive heat exchange. Compared to figure 2, $a$, in figure 2, $b$ the heat transfer through the system of two layers is impeded, due to the lower porosity of Sample $Y(23.3 \%)$. There is still influence of the main flow on the convective cross flow, but the

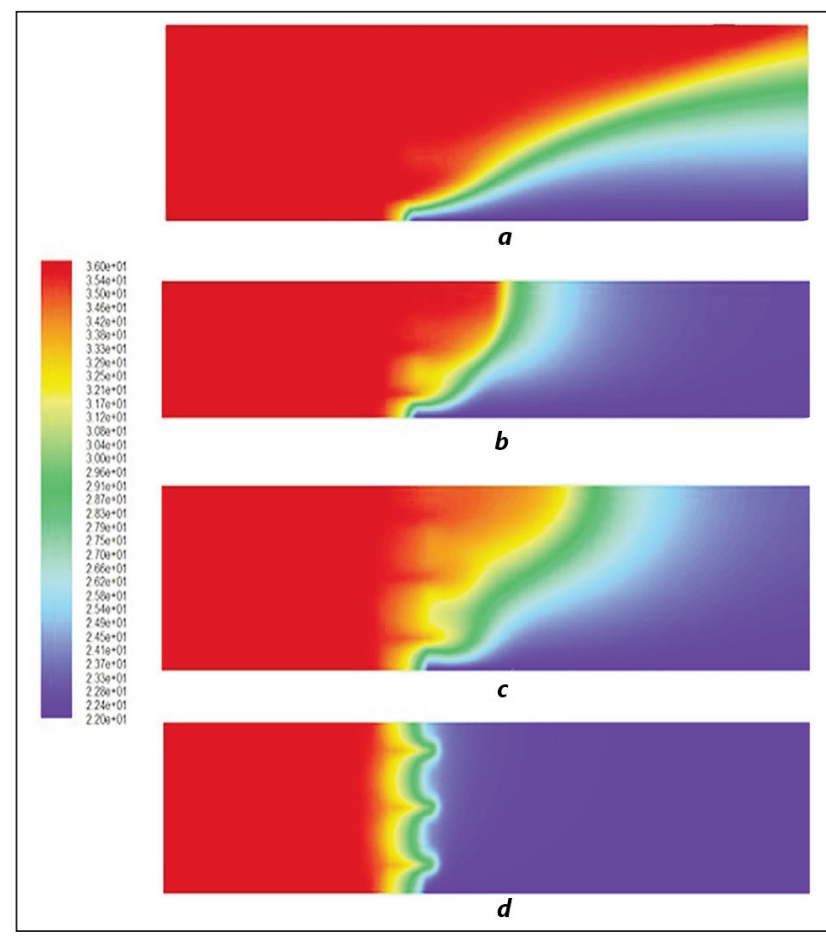

Fig. 2. Temperature field: $a$ - Case $1 ; b-$ Case 3; $c$ - Case $5 ; d$ - Case 6

process is less intensive. The same is valid for figure 2, $c$ and figure 2, $d$ : the porosity of Samples $S$ and $R$ is very low, while their thickness increases, that leads to a continuous decrement of the heat transfer through the system, reaching suspension of the heat flow in figure $2, d$. The temperature drop is relatively low after the first layer (Sample P), but the second layer (Sample R), which porosity is $8.9 \%$, plays the role of best insulation layer: the heat on the left side of the domain is retained by the textile barrier (Case 6). Figure 3 shows the static pressure field for the same cases. Three main areas can be easily distinguished,

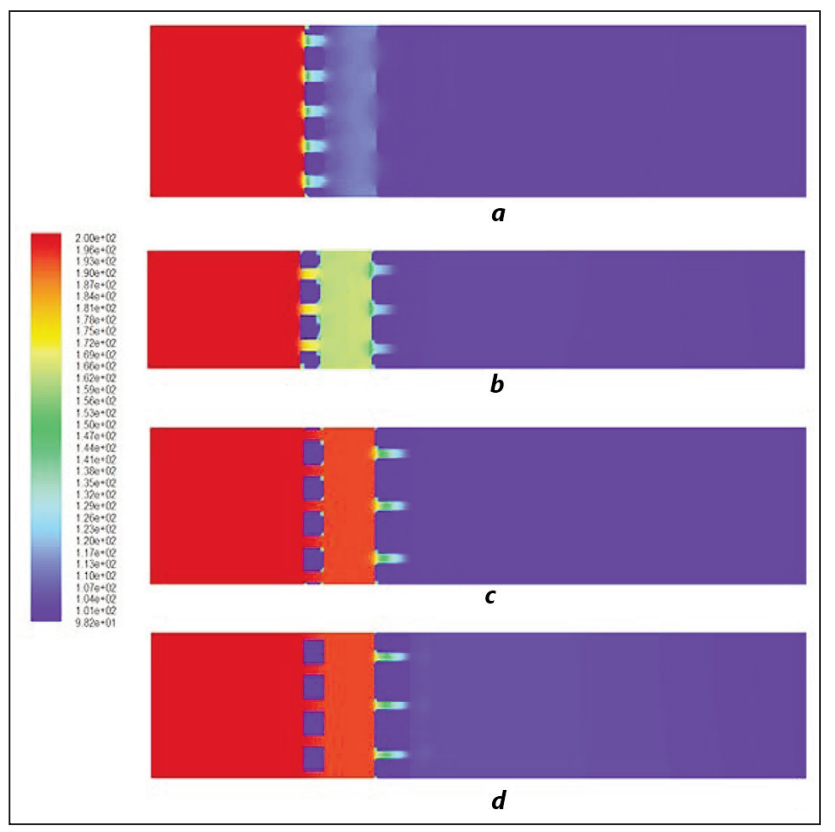

Fig. 3. Static pressure field: $a$ - Case $1 ; b$ - Case 3; $c$ - Case $5 ; d$-Case 6 
which clearly depict the stages of pressure change: before the first sample, between the samples and after the second sample. The sudden change in the fluid pressure after the first sample is obvious for figures 3 , $a$ and $b$, as the first layer is of low porosity and pressure losses are consequently greater. The high porosity of the textile barrier accounts for the almost unchanged static pressure after the second layer (figure $3, a$ ). This is the reason for the almost the same static pressure after the first layer in Case 5 (figure 3,c) and Case 6 (figure 3,d).

The effect of the arrangement of the layers in the system

Figure 4 presents the temperature field for Cases 1 and 2 and figure 5 - for Cases 3 and 4 . The differ- ence in each pair of cases is the arrangement of the two layers (table 2).

Figure 6, which shows the streamlines with the temperature map for Cases 1 and 2 is very appropriate to discuss the temperature fields in figures 4 and 5 . The numerical results show that the transfer of heat is more intensive when the more porous layer is on the second place (figures $4, a$ and $6, a$ ). The practical meaning is that in a clothing ensemble of two layers with different porosity, if the less porous layer is closer to the skin, the transfer of heat from the skin through the clothing to the environment will be higher. If the more porous layer is next to the skin and the less porous is the outside layer, the clothing will assure higher thermal insulation. Figure 6, a shows once again the intensive heat transfer in Case 1 that is barely influenced by the convective cross flow after

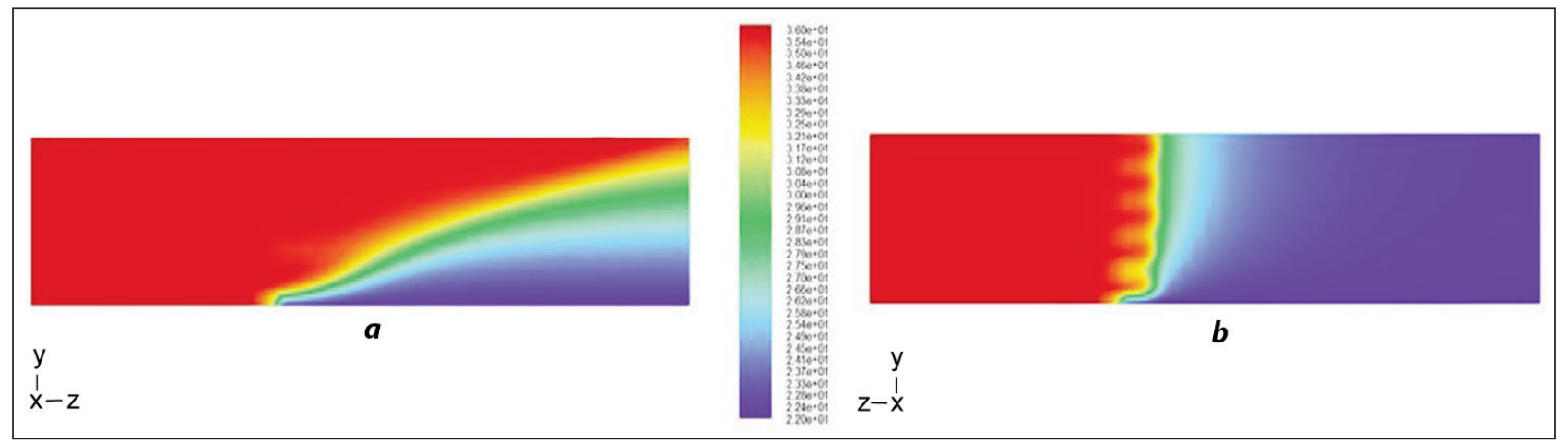

Fig. 4. Temperature field: $a$ - Case $1 ; b$ - Case 2

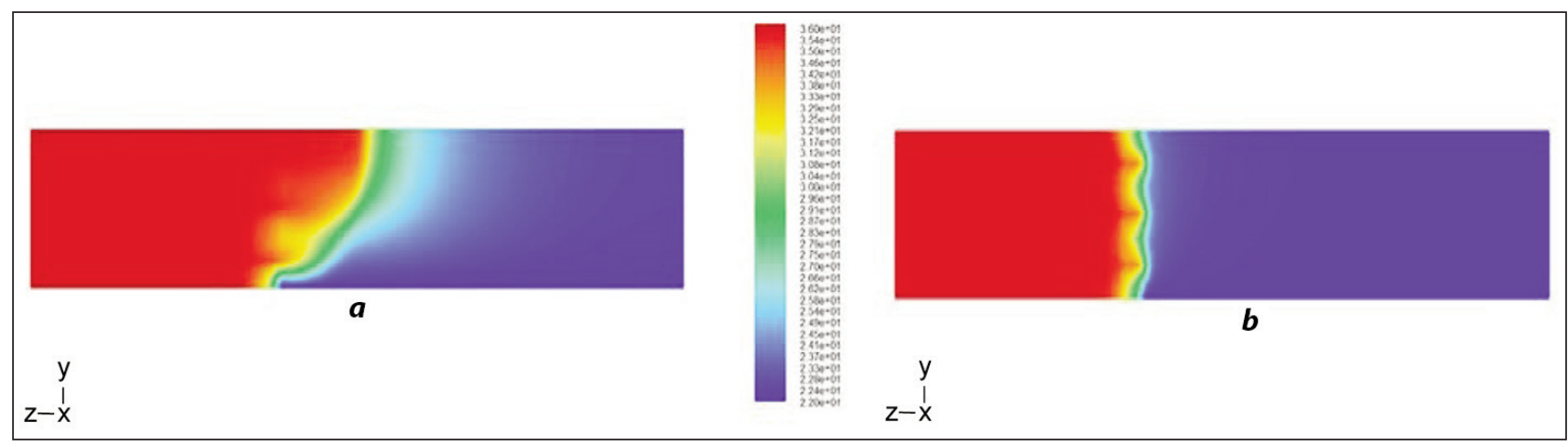

Fig. 5. Temperature field: $a$ - Case $3 ; b$ - Case 4

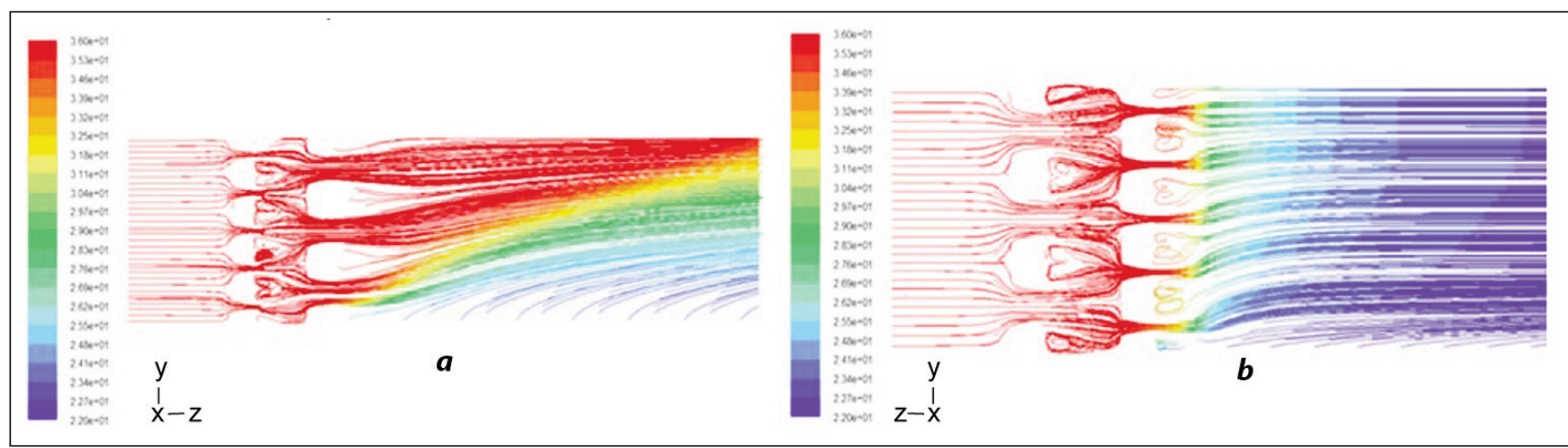

Fig. 6. Streamlines with temperature field: $a$ - Case $1 ; b$ - Case 2 
the textile. In Case 2 (figure 6, $b$ ), on the contrary, the temperature after the second layer is much lower and the convective cross-flow transports the heat in the vertical plane.

\section{CONCLUSIONS}

The process of heat transfer through various woven macrostructures and their combination were numerically simulated and analysed from the point of view of the interaction between the human body (skin) and the indoor environment. The effect of the porosity and thickness of the single layers on the heat transfer through the compound two-layer system was numerically proven and analysed. The effect of the arrangement of the layers in the systems on the heat transfer was also analysed with practical conclusions for design of clothing items.
The scientific contribution of this work lies in the way of simulation of the woven fabrics, based on jet-system theory and the novelties, related to the influence of the characteristics of the woven macrostructures and their arrangement in the two-layer system on the heat transfer. The results obtained allow to conclude that the proposed method for simulation could be applied for both further research on the topic (i.e. simulating more layers of different types) and designing clothing ensembles with desired insulating performance.

\section{ACHNOWLEDGEMENT}

The authors would like to thank the Research and Development Sector at the Technical University of Sofia for the financial support for the publishing of the present research

\section{REFERENCES}

[1] Henry, P.S.H., Diffusion in absorbing media, In: Proceedings of the Royal Society of London A: Mathematical, Physical and Engineering Sciences, 1939, 171, 945, 215-241

[2] Ogniewicz, Y., Tien, C.L., Analysis of condensation in porous insulation, In: International Journal of Heat and Mass Transfer, 1981, 24, 3, 421-429

[3] Farnworth, B., A numerical model of the combined diffusion of heat and water vapor through clothing, In: Textile Research Journal, 1986, 56, 11, 653-665

[4] Fan, J., Cheng, X.Y., Heat and moisture transfer with sorption and phase change through clothing assemblies. Part I: Experimental investigation, In: Textile Research Journal, 2005, 75, 2, 99-105

[5] Wissler, E.H., Havenith, G., A simple theoretical model of heat and moisture transport in multi-layer garments in cool ambient air, In: European journal of applied physiology, 2009, 105, 5, 797-808

[6] Li, Y., Holcombe, B.V., Mathematical simulation of heat and moisture transfer in a human-clothing-environment system, In: Textile Research Journal, 1998, 68, 6, 389-397

[7] Gagge, A.P., An effective temperature scale based on a simple model of human physiological regulatory response, In: ASHRAE Transactions, 1971, 77, 2, 247-262

[8] De Dear, R.J., Arens, E., Hui, Z., Oguro, M., Convective and radiative heat transfer coefficients for individual human body segments, In: International Journal of Biometeorology, 1997, 40, 3, 141-156

[9] Xu, X., Werner, J., A Dynamic Model of the Humall/Clothing/Envirorllnent-System, In: Applied human science, $1987,16,2,61-75$

[10] Fiala, D., Lomas, K.J., Stohrer, M., A computer model of human thermoregulation for a wide range of environmental conditions: the passive system, In: Journal of Applied Physiology, 1999, 87, 5, 1957-1972

[11] Angelova, R.A., Textiles and human thermophysiological comfort in the indoor environment, Boca Raton: CRC Press, 2016

[12] Angelova, R.A., Kyosov, M., Stankov, P., Numerical investigation of the heat transfer through woven textiles by the jet system theory, In: The Journal of The Textile Institute, 2018, 1-10

[13] Angelova, R., Determination of the pore size of woven structures through image analysis, In: Open Engineering, 2012, 2, 1, 129-135

[14] Stankov, P., Three dimensional turbulent flows in heat and mass transfer processes, DSc Thesis, Technical University of Sofia, Bulgaria, 1998

\section{Authors:}

\section{ANGELOVA A.RADOSTINA ${ }^{1}$, MIROSLAV KYOSOV², PETER STANKOV ${ }^{2}$}

${ }^{1}$ Technical University of Sofia, Department of Textiles, 1000 Sofia, Bulgaria

${ }^{2}$ Technical University of Sofia, Centre for Research and Design in Human Comfort, Energy and Environment (CERDECEN), 1000, Sofia, Bulgaria

e-mail: mircho@abv.bg, peter.stankov@abv.bg

Corresponding author:

ANGELOVA A. RADOSTINA

e-mail: joy_angels@abv.bg 